\title{
Neoliberalny panoptykon biopolityki - pomiędzy ekspansją i społeczną terapią
}

\section{The Neoliberal Panopticon of Biopolitics - Between Expansion and}

\section{Social Therapy}

\begin{abstract}
Human enhancement technologies raise serious ethical questions about health practices no longer content simply to treat disease, but which now also propose to "optimize" human beings' physical, cognitive and psychological abilities. In this article we undertake some conceptual clarification of the concepts of biopower and biopolitics and argue for their utility in contemporary analysis. Three decades of neoliberal policies have seriously reduced the welfare state: privatisations and cuts in public budgets have forced public agencies to downsize their activities, sometimes losing universality, effectiveness and quality of services. The pandemic has dramatically shown the price of such a neoliberal turn. Market globalisation creates health threats and is completely unable to respond to emergencies. Private health care is turning out to be largely irrelevant in facing the pandemic. The welfare state should not be considered a 'cost' for the private economic system. It would be a mistake to believe that, once the pandemic has passed, the economy could go back to 'normal'. We need to rethink production and consumption considering health and environmental needs.
\end{abstract}

Keywords: panopticon of biopolitics, neoliberal way of development, crisis, digital technologies, social therapy

Znamienne są słowa brytyjskiego filozofa Johna Graya, mówiące o tym, że świat Zachodu na początku nowego tysiąclecia pokrywają ruiny utopijnych projektów, które - choć formułowane w języku świeckim, przeczącym religii, były w istocie nośnikami religijnych mitów (Gray, 2009, s. 9). Mitów racjonalności i samorealizacji, służących do promowania cywilizacyjnych zmian, mających zaszczepić pozostałym narodom nowe wzorce w celu wykorzenienia uprzedzeń, zwyczajów i starych tradycji. Jeśli u zarania dziejów kwestie związane z reprodukcją 
i podtrzymaniem życia nie przynależały do sfery publicznej ani politycznej, lecz prywatnej, to w czasach nowożytnych dokonano znamiennego przedefiniowania wszystkich istotnych idei politycznych na terminy odnoszące się do polityki życia ludzkiego. Zestawienie biologiczności z politycznością zaproponowane przez Arystotelesa stało się impulsem do postępującej transgresji obu sfer ludzkiej egzystencji - przenikania się natury biologicznej człowieka z czynnikiem społecznym. Wielu przedstawicieli nauk społecznych zaadaptowało wspomnianą transgresję do własnych koncepcji badawczych, promując tym samym pojawienie się w dyskursie naukowym zagadnień polityki rozumianych jako biologia polityki ${ }^{1}$. Pod pojęciem biopolityki należy rozumieć tendencję do coraz mocniejszego włączania naturalnego życia człowieka, jego organizmu i ciała, w mechanizmy i kalkulacje władzy. Przyjmuje się powszechnie, że biopolityka obejmuje te sfery polityki, które zajmują sią regulacją i sterowaniem procesami życia związanymi z praktykami modernizacji (Lemke, 2010, s. 9-10).

Spojrzenie na biopolitykę z perspektywy czynników o charakterze biologicznym jest dalece niewystarczające. W obecnych czasach możemy mówić o swoistym panoptykonie, powstałym $\mathrm{w}$ następstwie sprzężenia nowych technologii i rozwoju gospodarczego z marginalnym szacunkiem dla prywatności i zaborczością neoliberalnego państwa ${ }^{2}$. Wraz z postępem technologicznym i możliwością manipulacji danymi, zwiększoną dostępnością do codziennego życia oraz potencjałem zarządzania społecznego, nadzór stał się kluczowym miejscem do zrozumienia działania władzy w globalnej gospodarce. Google, Facebook czy Twitter pozostają lewiatanem uwolnionym od jakiegokolwiek nadzoru. Mierzą się ze światem nieświadomych konsumentów informacji, z których wielu zakłada, że to, co czytają, jest wiarygodne (Kreft, 2019). W rzeczywistości przekaz jest filtrowany przez złożoną sieć algorytmów i polityk, które eliminują niewygodne treści, aby utrzymać dominację. Oznacza to wystawienie oraz ujawnienie prywatnego życia człowieka w pełnym oglądzie przez globalne korporacje

1 W obrębie zróżnicowanego pola badawczego wyróżnić można cztery obszary, do których da się zakwalifikować większość prac. Pierwsza część związana jest z recepcją neodarwinistycznej teorii ewolucyjnej. W jej centrum stoi historyczno-antropologiczne pytanie o pochodzenie człowieka oraz początki państwa i społeczeństwa. Druga grupa badań przechwytuje etologiczne i socjobiologiczne koncepcje i wyniki badań, by uczynić je stosowalnymi do analiz zachowania politycznego. Do trzeciej kategorii należą prace, które interesują się czynnikami fizjologicznymi i ich możliwym wkładem w wyjaśnienie politycznie istotnych form działania. W przypadku czwartej grupy punkt ciężkości położono na praktyczno-polityczne problemy biopolicies, wynikające $\mathrm{z}$ ingerencji człowieka w jego własną naturę i ze zmian środowiskowych. Zob. Lemke, 2011, s. 14.

2 Filozof Jeremy Bentham, wykorzystując metaforę panoptykonu, nazwał tak projekt więzienia, w którym strażnicy mogli obserwować każdego z osadzonych z jednego miejsca w dowolnym czasie. Celem budowy panoptykonu była m.in., jak pisał Bentham, poprawa obyczajów, zgodnie z zasadą maksymalizacji szczęścia w społeczeństwie, i utrzymanie zdrowia więźniów, a przede wszystkim obniżenie kosztów więziennictwa dla publicznego budżetu. 
(serwery i specjalne aplikacje) lub innych użytkowników w sieci (blogi, portale społecznościowe). W tym sensie rewolucja cyfrowa staje się potężnym katalizatorem różnych wydarzeń oraz nagłych zwrotów akcji dla życia jednostek, społeczeństw i państw. W skali globalnej nowe technologie otworzyły przestrzeń dla nieformalnych form nadzoru, które mogą być skutecznie powiązane $\mathrm{z}$ media$\mathrm{mi}$ i odbiorcami internetowymi. Konsument nowych technologii z jednej strony ulega mirażom pokonywania kolejnych progów na drodze do spełnienia marzeń o wolności, a z drugiej strony wystawiony jest na działanie całego instrumentarium nacisków i ograniczeń, które owe technologie generują ${ }^{3}$.

Polityka zawsze polegała na próbach kształtowania postaw w jakiejś formie, co sprawia, że ów zamysł w ostatnich dekadach był szczególnie ważny, jeśli brać pod uwagę jego trzy powiązane czynniki. Pierwszym jest bardziej zróżnicowane i zindywidualizowane społeczeństwo, stwarzające wyzwania (np. w zakresie zdrowia publicznego, demografii czy zmian klimatu), którym mogą sprostać zmiany zachowań zarówno osób fizycznych, jak i instytucji. Drugim czynnikiem jest kontekst polityczny i ideologiczny (trzydzieści lat neoliberalizmu skutecznie zdyskredytowało wiarę w bezpośrednie działania państwa). Trzeci czynnik ma wymiar intelektualny, dotyczy bowiem szybkiego rozwoju nauk behawioralnych, inspirowanych przez ekonomię behawioralną i psychologię, które usiłowały podejmować próby modelowania zachowań człowieka. Wśród wielu refleksji Michela Foucaulta nad władzą i rządzeniem pojawia się krytyczny związek, jaki zaobserwował w liberalizmie między zarządzaniem a rządami państwa - rozumianymi jako sprawowanie politycznej suwerenności nad terytorium i jego ludnością ${ }^{4}$ Otwarcie rynków na wymianę zindywidualizowanych treści rodzi istotne pytania, czy przestrzenie komunikacyjne, które umożliwiają media cyfrowe, będą służyć działalności demokratycznej niezależnej władzy państwowej, czy też zaawansowane techniki obserwacji zwiększą możliwości panoptycznego nadzoru państwa i rynku.

Pomimo tego, iż z jednej strony udało się w pewien sposób ujarzmić świat polityki, nakładając na niego formę instytucjonalnych ograniczeń, to jednocześnie $\mathrm{z}$ drugiej strony pozostał - i to w niespotykanej dotąd skali - problem tego, co „polityczne”, tzn. tego, co tej instytucjonalizacji się wymyka ${ }^{5}$. Mamy tu do

Rozważania nad „produkcją zgody” Hermana i Chomskiego (w pracy Manufacturing Consent: The Political Economy of the Mass Media, London 1994), dotyczące przydatności modeli propagandy w opisie zawartości mediów, wskazują na jej funkcjonowanie również w rzeczywistości 2.0, zdominowanej przez media społecznościowe. Zob. Fuchs, 2018.

4 Liberalne metody rządzenia wyróżniają się sposobem, w jaki wykorzystują one możliwości swobodnie działających podmiotów, a co za tym idzie - tryby rządzenia różnią się pod względem wartości i definicji, jaką przypisuje się pojęciu wolności. Zob. Peters, 2007, s. $165-178$.

Twórcy polityki coraz bardziej wierzą, że w obliczu złożoności społecznej i zindywidualizowanego obywatelstwa - jedynym sposobem rozwiązania „groźnych” wyzwań, takich jak zmiany klimatyczne lub otyłość, jest zachęcenie samych obywateli do (na przykład) recyklingu lub 
czynienia z pytaniem o możliwość „skutecznego” działania, pytaniem o zakres tego, co należałoby nazwać emancypacyjnym potencjałem polityki ${ }^{6}$. W ślad za wspomnianym emancypacyjnym potencjałem pojawia się pytanie: Czy neoliberalizm powinien być analizowany jako „wielki lewiatan” - tło wyjaśniające, na podstawie którego rozumie się inne zjawiska i procesy?

\section{Człowiek w trybach maszynerii władzy}

Bardziej interdyscyplinarny, holistyczny wgląd $\mathrm{w}$ biopolitykę zaproponował Michel Foucault, ujawniając mechanizmy i dziedzinę kalkulacji wynikających z władzy-wiedzy jako czynnik przekształcania ludzkiego bytu (Foucault, 2000a, s. 125). Według autora „próg biologicznej nowoczesności” danego społeczeństwa ujawnia się w momencie, gdy ciało człowieka, jego ruchy i aktywność w miejscach publicznych (szkoły, fabryki), jak i w sferze prywatnej (choroby psychiczne, seksualność) stają się przedmiotem zainteresowania władzy i jej praktyk. Pojęcie biopolityki w pismach Foucaulta odnosi się do rozwoju swoistej wiedzy i nowych dyscyplin, takich jak statystyka, demografia, epidemiologia i biologia, które analizują procesy życiowe na poziomie populacji, aby „rządzić” jednostkami i kolektywami poprzez środki korygujące, dyscyplinujące, terapeutyczne czy optymalizujące 7 . W centrum uwagi Foucaulta znajduje się „ekonomia” polityki życia: kto i w jakiej formie czerpie korzyści z regulacji i optymalizacji procesów życiowych (przykładowo zysk finansowy, wpływ polityczny, prestiż społeczny), a kto ponosi koszty i cierpi z tego powodu (ubóstwo, choroba, przedwczesna śmierć). Od codziennych wyborów jednostek (co jeść, co poddawać recyklingowi) po działalność korporacji - zmiana zachowań stała się współczesnym mechanizmem politycznego wpływu ${ }^{8}$.

większej aktywności fizycznej. Zestaw narzędzi do tego podejścia został dostarczony przez ekonomię behawioralną opartą na psychologii społecznej. Zob. Leggett, 2014, s. 3-19.

6 Ważną ramą interpretacyjną spuścizny Foucaulta jest to, że neoliberalizm różni się od klasycznego liberalizmu - między innymi - aktywną rolą, jaką wyobraża sobie rząd w tworzeniu warunków dyfuzji rynków i mechanizmów rynkowych. Warto dyskutować o naturze tego konstruktywistycznego wymiaru neoliberalizmu oraz o roli, jaką odgrywają w nim instytucje rządowe i pozarządowe. Zob. Collier, 2012, s. 186-187.

7 Pojęcia „biowładzy” i „biopolityki” nierzadko są używane w odmienny sposób, ale warto myśleć o „biowładzy” jako podstawowej, leżącej u podstaw racjonalności kultywowania życia populacji, oraz „,biopolityce” jako zestawie narzędzi określających zakres różnych środków i technik. Zob. Rabinow, Rose, 2006, s. 195-217.

8 W związku z tym interesujące staje się pytanie, jakie formy adaptacji wynikają z poszczególnych rodzajów władzy. Można przyjrzeć się relacjom między władzą a oporem, odwołując się do „trójkąta” Foucaulta: a. suwerenna władza; b. władza dyscyplinarna; c. biowładza. Zob. Lilja, Vinthagen, 2014, s. 107-126. 
Pod względem historycznym i analitycznym Foucault wyróżnił dwa wymiary „władzy nad życiem”: dyscyplinowanie ciała jednostkowego z jednej strony oraz społeczną regulację „ciała populacji” z drugiej. Zgodnie z jego stwierdzeniem biopolityka wyznacza próg politycznej nowoczesności, ponieważ podejmowane czynności w centrum porządku politycznego stawiają życie ludzkie. Przyjęta perspektywa teoretyczna, jak i dotychczasowa praktyka uwidaczniają głęboki związek pomiędzy powstaniem społeczeństwa kapitalistycznego a narodzinami biopolityki. Foucault sugerował, że kapitalizm wprowadza techniki władzy, które podzielił na „dyscyplinarne” i „biopolityczne”. Przedmiotem działania tych pierwszych był „człowiek jako ciało”, podczas gdy drugie zajmowały się „człowiekiem jako gatunkiem”. I jedne, i drugie przeznaczone były dla „wielości ludzi”; jednak techniki dyscyplinarne miały za zadanie przekształcić wielość w ciała, techniki biopolityczne odnoszą się natomiast „do wielości ludzi”, o ile tworzą one globalną masę, dotyczącą ogólnych procesów właściwych życiu, takich jak narodziny, sposób życia, produkcja czy inne aspekty funkcjonowania człowieka. Naukowa refleksja i społeczno-polityczne spojrzenie na człowieka, na jego biologię i mechanizmy jego funkcjonowania, były docelowo skierowane na zmianę?.

Dla Foucaulta biopolityka stawała się historycznie wytworzonym, charakterystycznym dla nowożytności specyficznym sposobem urządzania życia populacji; natomiast biowładza - w bardziej technicznym tego słowa rozumieniu - była narzędziem tego sposobu urządzania nakierowanym na zwiększenie produktywności człowieka zgodnie z potrzebami rozwijającego się w tym czasie nowoczesnego społeczeństwa przemysłowego (Lemert, Gillan, 1999, s. 162). Obecna polityka, a wraz z nią procesy władcze lokują się coraz częściej poza państwem, $\mathrm{w}$ przestrzeniach przynależnych m.in. do globalnego rynku i jego wirtualnych wymiarów. W związku z tym, że współcześnie władza ulega rozproszeniu i występuje w wielu kontekstach, istotne jest odejście od ostrych granic między polityką, ekonomią i kulturą, które się przenikają, a stosunki władcze są lokowane w nowych obszarach, zderzanych z logiką zachodniego świata ${ }^{10}$. Analizy biopolityki nie można jednak odnosić tylko do osób, którym nie przysługują żadne prawa, na przykład uchodźców albo osób starających się o azyl. Musi obejmować ona wszystkich, którzy borykają się ze społecznym wykluczeniem, ludzi „bezużytecznych”, „niepotrzebnych” czy „zbędnych”, nawet jeśli formalnie cieszą się

9 Tak rozumiane człowieczeństwo i proces socjalizacji znajdują nowe miejsce w rzeczywistości - wspomina Jürgen Habermas - w której następuje przesunięcie od geocentryzmu do antropocentryzmu i od antropocentryzmu do biocentryzmu. Zob. Habermas, 2003, s. 63.

10 Nowe technologie otworzyły przestrzeń dla nieformalnych, lokalnych inspekcji, które mogą być skutecznie powiązane z mediami i odbiorcami internetowymi. Te „sieci nadzoru”, nieformalne sojusze różnych aktorów, mają potencjał do radykalnej zmiany ortodoksyjnych stosunków władzy poprzez unikanie kontroli informacyjnej państwa i łączenie lokalnego spojrzenia ze społecznością globalną. Zob. Green, 1999, s. 26-44. 
oni pełnią praw obywatelskich. Podczas gdy w przeszłości ci przedstawiciele zasiedlali wyłącznie peryferyjne przestrzenie w tak zwanym Trzecim Świecie, aktualnie w gospodarce globalnej takie formy wykluczenia można odnaleźć także w nowoczesnych krajach uprzemysłowionych ${ }^{11}$.

Dzisiejszy projekt zachodniej nowoczesności został powiązany z warunkami bytu na wyższym poziomie, związanym $\mathrm{z}$ dokonaniami w zakresie medycyny, technologii, ekonomii - innymi słowy - sakralizacją postępu poprzez rozum. W owym procesie samoistnego „obiektywizowania” i racjonalności postępu zaciera się jednakże różnica między tym, do czego on zmierza, a tym, co jest człowiekowi narzucone jako powinność. Próg nowoczesności naznaczony w pierwszym ujęciu pozwala na dostrzeżenie opcji zmian, jakie muszą zaistnieć w sferze „życia”, aby proces biopolityki mógł się rozwijać, będąc „troską o całość", gdzie osiągnięcie tego celu pozwala dobrać dowolne środki kontroli i interwencji. Środki masowego przekazu, rządzący i wszelkie ruchy społeczne skłonne są uzasadniać, że u podstaw ich działań leży troska o człowieka, o zdrowie jego ciała i umysłu. Wspomniana interwencja może być interpretowana jako wyraz dyrektyw prakseologicznych owej troski: odpowiedni przyrost demograficzny, zarządzanie opieką medyczną, bezpieczeństwo zdrowotne i społeczne czy starania o równowagę między szeroko rozumianym postępem a środowiskiem naturalnym. Wówczas rozwój człowieka związany byłby ze wzrostem potencjału intelektualnego i podmiotowości osób, narodów i społeczności, a także z odpowiednimi zmianami stosunków społecznych. Drugie ujęcie natomiast wydaje się być podporządkowaniem polityki warunkom biologicznym, pierwotnym, w pewien sposób atawistycznym. Należałoby sformułować pytanie o rozumienie sensu wydobywania naturalnych dynamizmów rozwoju człowieka, którym owa polityka miałaby hołdować ${ }^{12}$. Tu bowiem nie chodzi o poznanie człowieka jako takie, o badanie czy interpretowanie tego, co ludzkie, ale o ingerencję, posuniętą do granic manipulacji. Warto zwrócić uwagę na interesujący problem, w którym projekty zmian społecznych stają się nowymi nośnikami kapitalizmu, to znaczy style życia ulegają absorpcji przez rynek, ale nie funkcjonują jako mechanizmy, które go zmieniają. Dla Foucaulta biopolityka nie jest suwerenną decyzją o życiu lub śmierci, jak było to praktykowane przed epoką klasycyzmu, lecz projektem modelującym życie populacji i zwiększającym jej produktywność na potrzeby rozwijającego się społeczeństwa kapitalistycznego. Polityczna nowość biopolityki polega na tym, że - zdaniem autora - ogniskuje się ona na wartości

11 Praktyka życia społecznego nie wydaje się być bardziej nieskazitelna od swej poprzedniczki podkreśla Zygmunt Bauman - w sferze konceptualizacji pojęcia „dobro człowieka”. Wolność jest równie okaleczana jak przedtem, choć amputuje się dziś inne jej organy niż dawniej. Zob. Bauman, 1995, s. 313-315.

12 Nieprzypadkowo zjawisko „rozciągania się władzy na życie lub rozciągania się władzy na człowieka jako istoty żywej” zaczęto określać mianem biopolityki. Zob. Foucault, 1998, s. 237. 
produkcyjnej jednostek oraz populacji ${ }^{13}$. W rzeczywistości Foucault traktował biopolitykę jako zasadniczy element neoliberalnego sposobu rządzenia.

Podłożem dla biopolityki, do którego odwołuje się ona i nawiązuje, jest proces uspołecznienia, w którym sam podmiot podporządkowuje swój organizm zewnętrznej władzy kontrolnej. Władza wzmacnia „ciała” poprzez ekonomiczny sens użyteczności, jednocześnie osłabiając je poprzez deficyt politycznego uprzywilejowania. „Ciało ludzkie dostaje się w tryby maszynerii władzy, która dokonuje rewizji, rozbiera na części i na powrót je składa” (zob. Foucault, 1993, s. 164). Czyli po pierwszym zawłaszczeniu ciała, które dokonało się według modelu indywidualizacji, mamy drugie zawłaszczenie, które nie jest już indywidualizujące, ale umasawiające, które zwraca się nie do człowieka-ciała, ale człowieka-gatunku. Foucault nazwał ten proces „anatomią polityczną”, przeprowadzoną przez działania władzy z myślą o ujarzmieniu człowieka, jego ciała - nie po to, aby wyglądało ono tak, jak tego chce, lecz aby działało tak, jak powinno. Urynkowienie jednostki było osiągalne dzięki restrukturyzacji podmiotowości, poddaniu jej racjonalności ekonomicznej zysków i strat. Potrzebny był człowiek o mentalności globalnej, nastawiony na potrzebę osiągnięć, wyzwolony z tożsamości kolektywnej, ujednostkowiony i sprowadzony do wymiaru konsumenta. Z czasem ta idea stała się samospełniającą mantrą, w której „media o modzie i urodzie" były władne skolonizować ludzkie oczekiwania dotyczące przyszłości. Erozja solidarności społecznej i wzrost indywidualizacji stworzyły klimat, w którym zakupy wydają się mieć większe znaczenie niż uczestnictwo demokratyczne. I właśnie dlatego politycy wydają się być zdyskredytowani, a lobbyści i rzecznicy biznesu mogą zażądać dla siebie nowej roli, mającej być rzekomym głosem ludu ${ }^{14}$.

Niełatwo w tej aurze fasadowości zachować ufność wobec relacji nacechowanych komercyjną pragmatyką gry o zaufanie, z pominięciem wartości konstytuujących podmiotowy wymiar egzystencji człowieka. Wymowne jest to, że w narcystycznej epoce słowa „ja” i „moje” stały się centralną cechą słownictwa. Kultura obrazu stawiająca na wizualność, promowanie atrakcyjnego wyglądu ma ważkie konsekwencje, sfera polityki posługuje się metodą castingu. Można mówić o trywializacji i emocjonalizacji życia publicznego, w którym dominuje kultura

13 Nie zastąpiono duszy, iluzji teologów, rzeczywistym człowiekiem, przedmiotem wiedzy, refleksji filozoficznej i technicznej interwencji. Człowiek, o którym tyle nam mówią i do wyzwolenia którego wzywają, jest już, sam w sobie, wynikiem o wiele głębszego ujarzmienia. Zob. Foucault, 1993, s. 37.

14 Dyskusja o tabloidyzacji wiąże się z potrzebą świadomego obywatela i jego zdolnością do wykonywania swoich demokratycznych obowiązków (choć istnieją różne poglądy na to, jak najlepiej to osiągnąć). Ponieważ konsumpcja wiadomości w coraz większym stopniu przenosi się do Internetu - tym, którzy zdecydowali się tylko na kontakt z wiadomościami online, oferuje się proporcjonalnie mniej wiadomości informujących ich o społeczeństwie, a więcej wiadomości adresowanych do nich jako konsumentów. Zob. Bo Karlsson, 2016, s. 162. 
obrazkowa, a nie oświeceniowa, racjonalna logika. Zjawiska i procesy polityczne to węzły gordyjskie grupowych interesów, zmiennego poparcia społecznego, konfliktów i kompromisów czy złożone procedury instytucjonalne i zależności techniczne. Natomiast praktyki medialne kierują się prostą logiką; przykuć uwagę, spersonalizować konflikt, dodać efekt zaskoczenia i pamiętać o krótkim czasie trwania widowiska. Stąd: dramatyzacja, łatwa narracja, walor rozrywkowy ${ }^{15}$. Praktyki i techniki podobne do stosowanych w psychoterapii stały się osnową sprawowania władzy i wywierania wpływu, a polityka behawioralna odzwierciedla pogoń za „uzyskaniem nieograniczonego dostępu do sfery ludzkiej subiektywności”. Podejmowane działania sprawiają, że rozrywka schlebiająca najniższym gustom przenika dziś kulturę masową, natomiast kultura wyższego rzędu, jako nierozrywkowa, wypychana jest na margines albo co gorsza - sama zostaje „urozrywkowiona”. Gospodarka wymaga popytu, czyli tworzenia nowych potrzeb, dlatego na pierwszy plan wysuwa się możliwość doboru treści w przekazach uwzględniająca wzrost konsumpcji do podniesienia możliwości sprzedaży, większe znaczenie obrazu i dźwięku, a spadek znaczenia druku, więcej treści o charakterze emocjonalnym niż analityczno-racjonalnym.

To sprawia, że rynek działa jak potężny organ ssący - przystosowany do czerpania energii, zasysając coraz więcej sfer życia publicznego. Zmieniła się natura tego rynku: nie jest to ani rynek moralny, jaki wyidealizował w swym umyśle Adam Smith, ani brutalny z czasów kapitalizmu manchesterskiego, lecz rynek, który działa jako uniwersalny locus życia społecznego, ekonomicznego, kulturalnego, a także coraz częściej politycznego. Jest to rynek, który redukuje tradycyjne funkcje państwa, utrzymuje tylko te najbardziej funkcjonalne, który pochłania coraz większe odłamy sfery publicznej ${ }^{16}$. Zamysłem takiej normy zachowania nie jest służba człowiekowi, lecz „wytwarzanie kulturowych wartości niezbędnych dla rozwoju konsumpcji”. Jest to tym bardziej podstępne, że tworząc pozory wyzwalania i możliwości realizacji własnych (a w rzeczywistości: narzuconych) potrzeb, pozostaje na usługach „sztuki sprzedawania marzeń”. Gloryfikowanie postępowości, kładące akcent na modernizację kulturową, zmianę stylu życia, obyczajów, przy traktowaniu modernizacji technologicznej

15 Badacze argumentują, że sytuacja może się jeszcze pogorszyć - w szczególności cyfryzacja zmienia sposób, w jaki dziennikarze dokonują oceny wiadomości, „tania, łatwa i popularna historia często wygrywa z drogimi, trudnymi i mniej popularnymi”. Zob. Bird, 2009, s. 40-50.

16 Chociaż „finanse globalne” niemal wykoleiły gospodarkę światową w latach 2007-2009, prawdziwa reforma sektora finansowego na całym obszarze Organizacji Współpracy Gospodarczej i Rozwoju (OECD) była dotychczas raczej ograniczona. Chociaż wiele banków i innych instytucji finansowych zostało uratowanych przez państwa kapitalistyczne, które przybyły na ratunek systemowi w ramach globalnego - wielomiliardowego ratunku, urzędnicy na całym świecie byli nieugięci w ogłaszaniu, że jest to tylko środek tymczasowy i że instytucje te zostaną "przywrócone na rynek”, gdy tylko pozwolą na to warunki. Zob. van Apeldoorn, Overbeek, 2012, s. 1-2. 
jako zadania wręcz wtórnego, jest specyficzną cechą myślenia dzisiejszego społeczeństwa, zakorzenioną w dominującym nurcie kultury masowej ${ }^{17}$.

Tendencję do ograniczania pożytku z umysłu można uznać za dominujący wyraz zachodniego życia politycznego i intelektualnego. Rozpadają się różnice między konsumentami a obywatelami oraz między gospodarką a polityką. Uniwersytety stały się fabrykami dyplomów, które są tylko przepustkami na rynek pracy, a społeczeństw Zachodu „nie zaprząta żadna batalia o idee”, bowiem horyzont intelektualny przeciętnego, wykształconego człowieka Zachodu wyznacza dziś Big Brother. Wyobrażenia traktujące proces indywidualizacji i prywatyzacji działań ludzkich jako coś naturalnego, spontanicznego i nieodwracalnego stanowią tylko ideologiczną legitymizację reguł gry kreowanych przez instytucje władające w społeczeństwie rynkowym. W tym procesie dobro publiczne staje się towarem, a struktury obywatelskie są zepchnięte do roli biernego uczestnika mediującego o bolesnych wyborach swojej przyszłej egzystencji. W miejsce solidaryzmu i wspólnotowego działania - niemalże niepisanym obowiązkiem społeczeństwa, a szczególnie jego „świadomych przedstawicieli”, jest poszukiwanie i urzeczywistnianie przyjemności.

Biopolityka jako nowoczesny proces funkcjonalizacji, wobec której świat staje się bardziej przewidywalny i obliczalny, a elementy magiczne ulegają wyparciu, na naszych oczach ulega wyraźnemu „odczarowaniu”. Ostatnie dekady unaoczniły złudność proponowanych rozwiązań, związanych z projektem ładu dążącego samoczynnie do szybkiego wzrostu (Peters, 2018, s. 323-325). Przyjęty model posunięć ekonomicznych posłużył jako przesłanka dla uzasadnienia i limitowania działań rządu, które zostały przez neoliberałów potraktowane jako rodzaj pomysłu zmierzającego do rywalizacji ekonomicznej między jednostka$\mathrm{mi}$, grupami i instytucjami ${ }^{18}$. Klasyczne niejako problemy systemu kapitalistycznego (dziś mówi się o kapitalizmie informacyjnym, cyfrowym, kognitywnym) nie znikają i są zapośredniczone przez nowe technologie. Rezultaty kamuflowanych sprzeczności i antynomii w sferze ekonomicznej zostały skutecznie przesłonięte koniecznością „wyzwań nowoczesności”. Można dość łatwo przewidzieć

17 „Nowa racjonalność rządzenia [biopolityczny liberalizm] potrzebuje wolności, bowiem tę wolność konsumuje. Konsumpcja wolności oznacza, że musi ją także wytwarzać”. Zob. Foucault, 2008, s. 63.

18 Podczas gdy ordoliberałowie europejscy posłużyli się pojęciem zarządzania społeczeństwem w imię regulacji ekonomii, przywołując ideę społecznego rynku ekonomicznego, który był nieustannie wzmacniany i wspierany regulacjami polityczno-prawnymi oraz działaniami społecznymi mającymi w zamierzeniu rozwinąć instytucje opiekuńcze, neoliberałowie amerykańscy zmierzali do przedefiniowania sfery społecznej jako kategorii podlegającej ocenie gry ekonomicznej. Thomas Piketty przekonywał, że nierówność nie jest przypadkiem, ale raczej endemiczną cechą kapitalizmu, którą można odwrócić tylko poprzez interwencję państwa, ponieważ zagraża ona ładowi demokratycznemu, jeśli kapitalizm nie zostanie zreformowany. Zob. Piketty, 2015. 
dalszą ekspansję wysiłków na rzecz utowarowienia polityki w ramach coraz bardziej powiązanych, panoptycznych strategii nadzoru ${ }^{19}$.

Ukryty $\mathrm{w}$ rynkowym fundamentalizmie potencjał społecznego darwinizmu znalazł upust nie tylko w polityce społecznej, ale i zagranicznej. Neoliberalny dyskurs o „normalności” kreował pewien integralny, zamknięty w ramach mechanizmu rynkowego świat, którego społeczne koszty zarazem ów dyskurs uwidaczniał, eksternalizując je, jak mówią ekonomiści, poza rynek, do gospodarki reprodukcyjnej. Jak wcześniej wskazywał Foucault, „władza dyscyplinarna (stwarzanie ciał i podmiotowości) oraz biowładza (zarządzanie populacjami) mają swoje korzenie w ekonomicznych wymaganiach systemu kapitalistycznego”. Kapitalizm „mógł przetrwać jedynie za cenę kontrolowanego wtłoczenia ciał w aparat wytwórczy i dostosowania zjawisk populacyjnych do procesów ekonomicznych" (Foucault, 2000a, s. 123).

Jednak praktyki przekształcania państwa poprzez zmiany aktów normatywnych, mających na celu jego izolowanie od konfliktów społecznych i politycznych, nie przyniosły zamierzonych rezultatów. Pozorne wzmocnienie państwa równocześnie pociągało za sobą jego rosnącą kruchość, ponieważ stawało się ono coraz bardziej celem szeregu protestów i niezadowolenia z powodu nacisków emanujących z tego wzmocnienia ${ }^{20}$. Wiek XXI jest świadkiem wzrostu światowego autorytaryzmu, który stara się zmobilizować populistyczną bazę, przedstawiając nosicieli globalizacji i nowoczesności jako zagrożenie dla narodu. W każdym przypadku ta grupa jest przedstawiana jako zagrożenie dla bezpieczeństwa narodowego i wartości, co wiąże się z destabilizującymi konsekwencjami globalizacji gospodarczej i politycznej: rosnącymi nierównościami, zmianami demograficznymi i deflacją krajowej władzy politycznej. Wśród spuścizny wolnorynkowych dogmatów można wymienić m.in. duże zadłużenie publiczne, recesję, stagnację gospodarczą, korupcję, duże strukturalne bezrobocie (zwłaszcza wśród młodych), starzenie się społeczeństw, niską konkurencyjność gospodarczą w porównaniu z Azją, kłopoty z emigrantami z Azji, Afryki, jak również narastanie fali populizmu i ksenofobii (Brysk, 2020).

19 Tworzenie i funkcjonowanie gospodarki rynkowej wymaga interwencji, choć innego rodzaju niż w przypadku prowadzenia gospodarki planowej. Zauważają to niektórzy ekonomiści i - w odróżnieniu od szkoły chicagowskiej - twierdzą, że rynki są konstrukcjami społecznymi i opierają się na szerokim zakresie regulacji instytucjonalnych i politycznych. Zob. Lemke, 2001, s. 190-207.

20 Chociaż korzyści ze wzrostu były niepewne, koszty w postaci zwiększonej zmienności gospodarczej i częstotliwości kryzysów wydają się bardziej oczywiste. Od 1980 roku miało miejsce około 150 epizodów gwałtownych wzrostów napływu kapitału w ponad 50 gospodarkach rynkowych; w około 20 procentach epizody te kończyły się kryzysem finansowym, a wiele z tych kryzysów wiąże się z dużymi spadkami produkcji. Zob. Ghosh, Ostry, Qureshi, 2016. 


\section{Behawioralny wymiar polityki terapeutycznej}

Pozornie mogłoby się wydawać, że ambicje i praktyki nadzorcze państwa w dobie globalizacji należą już do przeszłości. Opinie głoszące, iż państwo pod wpływem zmian we współczesnym świecie traci obszary swojego panowania, nie są do końca prawdziwe. Rezygnując $\mathrm{z}$ ambicji wywierania wpływu w sferze społeczno-ekonomicznej, instytucja państwa skwapliwie przesuwała swoje zainteresowania i aktywność w stronę wymiaru bezpieczeństwa i zindywidualizowanego obrazu jednostki. Retoryczne postulaty neoliberalnego rządzenia kosztem rozważań nad jego instytucjonalnymi cechami skłaniają do refleksji na temat presji na rynkowe i woluntarystyczne sposoby rządzenia, osadzone w zasadach zdecentralizowanej i zleconej na zewnątrz odpowiedzialności, z ograniczoną przestrzenią rozwiązań regulacyjnych (Bruff, 2014, s. 113-129). Narrację neoliberalną łatwiej można rozumieć jako ideologię, która zapewniała jedynie częściową reprezentację świata i której nieprawdziwy obraz ukrywał zasoby materialne przynoszące korzyści dominującym grupom interesu. Gdy odczytuje się ją jako ideologię, można uzyskać jaśniejszy obraz relacji między strategią neoliberalną a jej sprawnościowymi praktykami działania ${ }^{21}$. Zapewne historia ostatecznie oceni neoliberalizm jako projekt raczej skuteczniejszy w demontażu i unieszkodliwianiu alternatywnych formacji społecznych niż w skutecznym utrzymywaniu samookreślonej wolności rynkowej. Był on rzadko kojarzony z ustalonym repertuarem politycznym lub rdzeniem instytucjonalnym. Zamiast tego improwizował, rutynowo uciekając się do eksperymentowania, sprzyjał również strategiom rynkowym w połączeniu $\mathrm{z}$ wyjątkowością traktowania podmiotów korporacyjnych. $\mathrm{Z}$ biegiem czasu strategia bezpośredniej prywatyzacji rozmyła się $\mathrm{w}$ niezliczonych czynnikach sprawczych, takich jak partnerstwa publiczno-prywatne, ścisły monetaryzm uzasadniany polityką antyinflacyjną czy wybiórcza kategoryczność fiskalna otwierająca zdolności ekspansji wielkiego biznesu (Golinowski, 2018, s. 41-60).

Biowładza, stanowiąca zespół mechanizmów prowadzących do włączenia zasadniczych cech biologicznych gatunku ludzkiego w obszar polityki, stała się przedmiotem określonych strategii politycznych. Przy czym strategie polityczne przesuwające prawne i nadzorcze kompetencje ze sfery publicznej $\mathrm{w}$ sferę prywatną miały sygnalizować realizację projektu zindywidualizowanego społeczeństwa, eksponującego przyrost wolności, zróżnicowania i tolerancji do tego stopnia, że wszystkie style życia, nawet te uznawane za dewiacyjne, będą w nim akceptowane. W rzeczonym zamyśle neoliberalna agenda miała zaoferować wartości, które ochronią przed etnocentryzmami i nietolerancją, będą przydatne

21 Rozbieżność między neoliberalną teorią a praktyką polega na niepowodzeniu neoliberalnej teorii w uznaniu nieodłącznie osadzonej społecznie natury kapitalistycznej gospodarki. Innymi słowy, sprzeczności są częścią „pakietu”. Zob. Cahill, 2012, s. 115. 
w procesie adaptacji do rynku i otwartego społeczeństwa. We wspomnianych wzorach kulturowych dostrzegano walory terapeutyczne, miały one rozbudzać potrzebę osiągnięć, uczyć otwartości i patrzenia w przyszłość bez ustawicznego nurzania się w przeszłości.

Rozstanie z minionym doświadczeniem dało początek tendencjom do trwałego rozpraszania informacji i wzorów zachowań. W pomyśle zindywidualizowanego społeczeństwa współczesny człowiek został postawiony wobec nowych konfliktów i sprzeczności absolutnie niejednorodnych, ale ukierunkowanych na sytuacje i osoby. Biopolityka nie musiała już dysponować centrum władzy, bowiem współczesnym wzorem stał się , indywidualizm masowy”, uosabiający potencjał modernizacji, jak i kierunek dalszej jego egzystencji (Sloterdijk, 2003, s. 13). Ów system indywidualizacji zawierał równocześnie zarodki nowej etyki, która opiera się na zasadzie „obowiązków wobec samego siebie”. Stanowił on antynomię w stosunku do tradycyjnej etyki, bo obowiązki mają z konieczności charakter społeczny i działanie jednostek winno pozostawać w zgodzie z całością i być w nią włączone. Orientacje na nowe wartości mogły być pochopnie rozumiane jako wyraz egoizmu i narcyzmu. Jednak w podejmowanych praktykach rozpoznana zostaje istota tego, co nowe. Chodzi tu o samooświecenie i samowyzwolenie jako praktyczny proces życiowy, obejmujący także poszukiwanie nowych więzi społecznych w rodzinie, pracy i polityce. W trakcie procesów indywidualizacji systematycznie rozbudzano oczekiwania na „kawałek własnego życia”. Powstały nowe ruchy społeczne, które wypróbowują metody obchodzenia się z własnym ciałem i życiem $\mathrm{w}$ różnych wariantach kultury alternatywnej albo subkultury młodzieżowej ${ }^{22}$.

Kapitalizm popychany logiką mechanizmu konkurencji zniszczył moderujące formy kultury, zanim społeczeństwa zdążyły rozwinąć nowe wzory, które utrzymywałyby jego nową postać, a jednocześnie podtrzymywały jego progresywne elementy. O ile jeszcze niedawno w społeczeństwie dominowały postawy propagujące życie według określonych zasad, o tyle obecnie niemalże obowiązkiem jego członków jest poszukiwanie i urzeczywistnianie przyjemności. Za postawę prospołeczną uważa się aktywny udział w masowej konsumpcji, a kreowanie zdolności do konsumpcji tworzy nową obyczajowość, która usprawiedliwia radość polegającą na otaczaniu się produktami. Innymi słowy konsumpcję uznano za główną narrację codzienności, stanowiącą ostateczne kryterium postępu oraz sukcesu. Przyjęta forma obowiązków wobec samego siebie, a więc samoobserwacji i samopoznania, jest szczególnie istotna w epoce Internetu, gdzie

22 Poparcie dla idei znajdujących się na skrajnie prawicowej lub skrajnie lewicowej części światopoglądowego spektrum jest często postrzegane jako głos protestu przeciwko polityce głównego nurtu lub całemu systemowi politycznemu. Polityczni prawicowi i lewicowi zwolennicy są przedstawiani jako zasadniczo różne istoty, z zasadniczo różnymi światopoglądami, przekonaniami i opiniami politycznymi, lękami i obawami oraz innym poczuciem moralności. Zob. Kutiyski, Krouwel, van Prooijen, 2019. 
specjalistyczne serwisy i aplikacje dostarczają kategorii do nazwania wyborów konsumpcyjnych, proponują ich klasyfikacje, podpowiadają inne, potencjalnie interesujące nas dobra, czy też pozwalają precyzyjnie monitorować konsumenckie wybory (Campbell, 2006, s. 48-51). Dostarczanie ciągłego strumienia nowości w sytuacji, gdy rzeczy i nowinki technologiczne z czasem tracą walory atrakcyjności - sprawia, że w swojej wieloznaczności takie formy mogą wzbudzić zainteresowanie, zaangażowanie i radość.

Szybkie zmiany w dziedzinie technologii i zaskakujące wynalazki zwiększyły poziom i zakres niepewności społeczeństw i jednostek, osłabiły poczucie ciągłości, zachwiały poczuciem trwałości oraz wprowadziły nieznane wcześniej zagrożenia i niebezpieczeństwa. Być może mamy tu do czynienia ze swego rodzaju prawem: skala niepewności i egzystencjalnego niepokoju jest proporcjonalna do sukcesów technologii. Nie brakuje dowodów, że niezauważalna może być także granica między wiedzą a destrukcją. W konsekwencji ludzie wpadają w labirynt niepewności, a niekończące się oczekiwanie na pytania: „czy się realizuję?”, „kim właściwie jestem?” - rodzi coraz to nowe odpowiedzi. Są one w wieloraki sposób przetwarzane przez rynki ekspertów, przemysłu i ruchów religijnych ${ }^{23}$. W poszukiwaniu samospełnienia ludzie podróżują zgodnie z turystycznym katalogiem do wszystkich zakątków świata. Dewastują dotychczasowe związki rodzinne, szybko nawiązują nowe relacje, oddają się szkoleniom, uprawiają jogging, zmieniają często grupy terapeutyczne, owładnięci celem samorealizacji, aby sprawdzić stan swojego samopoczucia fizycznego i psychiczne$\mathrm{go}^{24}$. Alarmistyczne ostrzeżenia o bezprecedensowych zagrożeniach nieustannie podsycają poczucie nieufności, a panika, związana z bezpieczeństwem dzieci, nowymi technologiami, zdrowiem i produktami spożywczymi, stała się rutyną, zwłaszcza że cykle paniki następują po sobie w krótkich odstępach czasu i dotyczą coraz większej liczby tematów. Głównym beneficjentem tego procesu jest aktywizm konsumencki, który usiłuje wypromować się jako wiarygodne źródło autorytetu. W tym sensie wszelkie ruchy społeczne (m.in. ekologiczne, feministyczne, wegańsko-wegetariańskie) są z jednej strony wyrazem pojawiających się $\mathrm{w}$ społeczeństwie nowych sprzeczności, z drugiej zaś ich formy polityzacji

23 Ruchy populistyczne mogą reprezentować, choć w skrajnie spolaryzowany sposób, dwie strony tego samego medalu. Ich siła, oparta na wzbudzaniu strachu, prędzej czy później ujawnia swoje granice, podczas gdy prawdziwy problem, związek między nierównościami ekonomicznymi a niezadowoleniem z establishmentu, pozostaje nietknięty, podkopując kruche demokratyczne instytucje. Zob. Bruno, 2018.

24 Jednostki w społeczeństwie pozbawionym oparcia w trwałych instytucjach doświadczają braku zakorzenienia, stąd funkcjonują w poczuciu niepewności. Ten deficyt wspólnoty rekompensuje rynek sprawiający, że człowiek zredukowany jest do kategorii konsumenta. Według Barbera „W gruncie rzeczy to nie jest żadna tożsamość, tylko powłoka nakładana, żeby przykryć nagość”. Zob. Barber, 2008, s. 381. 
wynikają z procesów tworzenia nowych tożsamości w zindywidualizowanych przestrzeniach życia codziennego.

Naprzeciw owej bezsilności, ujawniającej deficyt bezpieczeństwa i poczucia szczęścia, wychodzi oferta mass mediów. Polityka stylu życia skolonizowana przez instrumenty behawioralnego wpływu jest bardzo wydajnym narzędziem zagospodarowania energii społeczeństwa ${ }^{25}$. W miarę jak problemy społeczne ulegają marginalizacji i zatracają właściwe kierunki działania, prywatne dążenia i sprawy osobiste zostają przeniesione w sferę publiczną (Beck, Beck-Gemsheim, 2002). Popularność tej polityki sprawia, że miejsce tradycyjnych autorytetów zajmują nauczyciele stylu życia: instruktorzy fitnessu, kucharze, doradcy do spraw kariery czy piosenkarze, którzy powiedzą nam, jak być dobrą matką, wrażliwym kochankiem i jak uwierzyć w siebie. Wielu polityków, niezdolnych nadać jakikolwiek sens życiu społecznemu, czemukolwiek istniejącemu poza indywidualnym „ja”, woli manipulować emocjami. Namiętność, którą dawniej budziły spory ideologiczne dotyczące przyszłości, dzisiaj zastępuje naganne postępowanie jednostki, kłopoty osobiste lub konflikty osobowościowe (Furedi, 2003, s. 33-37). Wystarczy, że specjaliści od badania rynku zidentyfikują dysponentów siły nabywczej, aby natychmiast wykreowano produkt lub usługę i wmówiono ludziom, że są im niezbędne do życia. Natomiast potrzeby, za którymi nie stoi siła nabywcza - są całkowicie ignorowane. Im bardziej drastyczne dla społeczeństwa są skutki liberalizacji w sferze ekonomicznej i społecznej, tym szybciej dochodzą do głosu środowiska biznesowe, które „sprzedają obietnicę bezpieczeństwa i szczęścia”"26 (przykładowo przedsiębiorstwo zajmujące się produkcją oraz sprzedażą mebli, a także artykułów dekoracyjnych - Ikea - moderuje styl życia, wypowiadając się w kwestiach światopoglądowych i praw człowieka).

Kultura bezpieczeństwa i szczęścia jest coraz bardziej postrzegana przez pryzmat tego, kim powinniśmy być i co powinniśmy mieć, aby przez to osiągnąć iluzoryczny cel. Niektórzy argumentują, że weganizm jest przykładem nowego, kompleksowego i refleksyjnego stylu życia konsumentów i obywateli. Refleksyjnym projektem osobistym byłoby także rozważenie, w jaki sposób wybory z życia codziennego, takie jak - w co się ubrać do pracy i jak się tam dostać (środek transportu), wpływają na odpowiedzialność za zmiany klimatu, przyszłe życie.

25 Obecnie prywatność i intymność, stanowiące głęboką, istotną część ludzkiego rozwoju, ulegają reorientacji; im więcej ujawniasz, tym bardziej jesteś szanowany. Dzisiaj nawet przyznanie się, że ktoś ukrywa tajemnicę, grozi publicznym potępieniem za niechęć do jej ujawnienia. W ten sposób udawanie ignorancji - celowo lub nieświadomie, zbiorowo lub indywidualnie - odpowiada dwóm postulatom, by wydawać się przejrzystym, jednocześnie sprawując kontrolę nad tą samą informacją, którą chce się ukryć. Zob. McGoey, 2007, s. 216-217.

26 Konsumpcję polityczną należy postrzegać jako część neoliberalnej kultury, która sprzyja indywidualizmowi, przenosi odpowiedzialność na konsumenta i osłabia odpowiedzialność obywatelską. Zob. Johnston, Szabo, 2011, s. 303-319. 
a także zagospodarowanie planety. Tacy entuzjaści przedstawiają szczęście jako coś wypływającego z wnętrza jednostki, jako owoc zaspokajania własnych emocjonalnych potrzeb, a najbardziej gorliwi spośród nich dowodzą, że nawet samo szczęście staje się pewnym problemem, jeżeli jego osiągnięcie zależy w zbyt dużym stopniu od innych ludzi. Zwrot w stronę terapii, którego wyrazem jest polityka behawioralna, kryje w sobie przekonanie, że ludzie "potrzebują wsparcia”, aby poradzić sobie z dolegającym im poczuciem frustracji. W ten sposób dorosłych obywateli traktuje się jak zawiedzione dzieci i może dlatego namawia się ich, aby dołączyli do chóru osób wyznających tę normalnośćc ${ }^{27}$.

U podłoża dążenia do władzy terapeutycznej leży przekonanie, że jednostkę ludzką cechuje chwiejność. Człowieka nie postrzega się już jako stanowiącego o sobie podmiotu, zdolnego do odgrywania roli obywatela, lecz jako potencjalnie „uszkodzony towar”, wymagający wsparcia zawodowców i armii terapeutów, którzy wiedzą, jak osiągnąć szczęście. Dzisiejsze programy szczęśliwości przesycone są tym antydemokratycznym nastawieniem, a ludzie nie tyle są zachęcani przez władzę do działania, ile raczej są przez nią „,wspierani” i „leczeni”. Jednym słowem mamy elitę, która usiłuje zaprezentować społeczeństwo jako zbiorowość oraz kierować jego członkami jako swoimi klientami i pacjentami. Władza bardzo łatwo może stać się terapeutą dla jednostek, a swoją funkcję postrzegać w kategoriach uzdrawiania społeczeństwa - bowiem wpisuje się w rolę kontrolera emocji. Wyobrażenie kategorii „niewystarczalność” przenosi się na wszystko, co dotąd funkcjonowało w zestawie reguł i określonych granic, których oczekuje się od wszystkich i w których społeczeństwa podlegają procesowi rozwoju, uniezależnienia się i emancypacji.

Tradycyjne granice, które oddzielają dorosłych od dzieci, mężczyzn od kobiet, ludzi od zwierząt, obywateli i nieobywateli czy prywatne od sfery publicznej, są często potępiane jako arbitralne, nienaturalne, a nawet niesprawiedliwe (Furedi, 2020). Wobec deficytu tych drogowskazów granica między dzieciństwem a dorosłością zaciera się, a wszyscy - zarówno młodzież, jak i dorośli - są zdezorientowani co do swoich ról, co powoduje zawstydzające zjawisko infantylizacji. Niektórzy dorośli mają obsesję na punkcie bycia „wiecznie młodym” i „ekstra”. Ojcowie noszą te same ubrania co ich synowie i słuchają tej samej muzyki, co prowadzi do „świadomego wysiłku, aby nie być ojcem lub matką dla dziecka, ale być ich najlepszym przyjacielem”. W rezultacie niektórzy rodzice zachowują się jak „przerośnięci chłopcy i dziewczęta", znosząc odpowiedzialność za utrzymanie wartości, z których ich dzieci mogłyby czerpać. Rodzice i nauczyciele robią wszystko, co w ich mocy, aby zostać przyjaciółmi młodych ludzi, a nie ich przewodnikami i mentorami. Podobne następstwa można dostrzec w edukacji, gdzie tradycyjne

27 Kryzys i następująca po nim „wielka recesja mogły wstrząsnąć supremacją neoliberalizmu, ale pozostaje on niekwestionowany przez poważne alternatywy i nadal kształtuje politykę po 2008 roku". Zob. Centeno, Cohen, 2012, s. 312. 
rozróżnienie między uczniami a studentami szybko zanika. W niektórych przypadkach infantylizacja studentów stała się karykaturą samą w sobie, a uniwersytety zapewniają studentów o niezbywalnych walorach podnoszenia wartości kształcenia. Istotnym obszarem społeczeństwa, w którym istniejące od tysiącleci granice ulegają załamaniu, są różnice płci. Rozmyciu ulega różnicowanie płci na podstawie anatomii i funkcji prokreacyjnych. Szybkość, z jaką kultura transpłciowa weszła do głównego nurtu zachodniego społeczeństwa, jest niezwykła. Zwolennicy rozmywania granic argumentują, że dotychczasowe podziały „utrudniają rozwój równości płci” i „naruszają tożsamość osób transseksualnych lub interseksualnych". Dyskurs o różnorodności to jedna z kluczowych wartości polityki tożsamości, aczkolwiek polityka tożsamości jest całkowicie wroga wobec wielości punktów widzenia. Argumentacja za pośrednictwem innej narracji, wynikającej z alternatywnej refleksji światopoglądowej, jest postrzegana jako obraźliwa, przywołująca wzgardę i uprzedzenia. Powyższe praktyki i identyfikacje niebinarne uległy tak mocnej instytucjonalizacji, że z powodzeniem przenikają do życia publicznego oraz kultury popularnej zachodniego świata.

Wydaje się, iż zachodnie społeczeństwo stało się tak wyobcowane w kwestii dokonywania ocen wartościujących, że stworzyło całe orwellowskie słownictwo, które oszczędza ludziom odpowiedzialności za dokonywanie ocen etycznych ${ }^{28}$. Zindywidualizowane „społeczeństwo niesamodzielnych” prowadzi do swoistej konsumpcji politycznej, odwracając uwagę obywateli od innych, istotnych form uczestnictwa w życiu politycznym. Bowiem reakcją aktywizmu klientów na rzeczywiste problemy demokratycznej odpowiedzialności jest całkowite jej unikanie na rzecz lobbingu grup interesu. Ów zamysł zdaje się stanowić solidne podstawy do modelowania postaw społeczeństwa, a wpływ, jaki jego produkty wywierają, nie tylko w sferze emocjonalnej, ale także na poziomie poznawczym, przekłada się na powstawanie treści istotnych dla siły tej kultury. Wybory konsumpcyjne i oferowana „wolność konsumpcyjna” pozostają całkowicie obojętne wobec istniejącego ładu i zupełnie pozbawione kontekstu społecznego. Odnosi się to nie tylko do codziennych zakupów, lecz także do wyborów dotyczących stylów życia, ofert wyborczych czy też modnych przekonań o świecie. O ile wcześniej media sprzyjały upodmiotowieniu represjonowanych mniejszości, o tyle obecnie tożsamość, która urasta do rangi najważniejszego wyróżnika społecznego, staje się siłą destrukcyjną skierowaną przeciwko demokracji liberalnej.

28 Wiele nowych narzędzi medialnych, takich jak Internet, służy zarówno jako narzędzie do organizowania wspólnych zasobów publicznych, jak i jako instrument do monitorowania życia prywatnego. To, że informacje polityczne są kupowane i sprzedawane, nie jest nowe. Jednak jakość produktu i struktura rynku znacznie się zmieniły, gdy organizacje zaczęły wykorzystywać nowe technologie medialne. Zob. Howard, Carr, Milstein, 2005, s. 59-73. 


\section{Neoliberalny obraz biopolityki wobec przesilenia}

Czy w świecie, który rozpoznaje coraz większą liczbę różnych tożsamości, dążenie do bardziej uniwersalnych wzorców jest zadaniem bez wyjścia? Czy jest możliwe, aby państwo i inne instytucje nadały kształt lub uruchomiły kolektywną solidarność? To pytania wychodzące naprzeciw czasom przed pandemią, czyli pytania dotyczace rozumienia ryzyka i niepewności. Od wiosny 2020 roku świat został postawiony wobec wydarzeń, które zdołały pozostawić w izolacji miliardy ludzi, zamrozić światową gospodarkę i wykluczyć większość organizacji międzynarodowych z gry. Uderzająca jest nieproporcjonalność przyczyn i skutków, bowiem wirus o stosunkowo niskiej śmiertelności miał poważny wpływ na wszystkie obszary świata, a nie podjęto skutecznych wysiłków w zakresie efektywnej koordynacji i nadzoru ${ }^{29}$.

Pandemia przekształciła się w ciągi zdarzeń tej rangi, ponieważ doskonale wpisała się w trendy, które rozpoczęły się na długo przed momentem zarejestrowania pierwszego przypadku nowego wirusa. Dotychczasowa prywatyzacja ubezpieczeń emerytalnych i zdrowotnych, systemu służby zdrowia i zabezpieczenia społecznego - wszystko to składało się na projekt społeczny, który - z uwagi na wiążące się z nim ryzyko i możliwe konsekwencje - trudno pogodzić z zasadami demokratycznego państwa ${ }^{30}$. Czy to oznacza, że era triumfu neoliberalizmu, z jego krytycznym podejściem do społecznych funkcji państwa i reform zmierzających do ograniczenia wydatków socjalnych, dobiegła końca? Radykalizm tego zwrotu będzie w dużej mierze zależał od poziomu rozwoju kraju przed kryzysem i tego, jak skutecznie poradził sobie z koronawirusem. Większość społecznych konsekwencji pandemii jest zgodna z wyzwaniami, przed którymi stanęły państwa, i w pewnym stopniu rozjaśnia ich przejawy.

Neoliberalizm zmarginalizował sieci bezpieczeństwa społecznego, systemy opieki zdrowotnej oraz inne elementy infrastruktury wspierające ludzkie życie. Jednocześnie neoliberalne reżimy we wszystkich skalach rozpieszczały i wspierały pakiety kapitału korporacyjnego w różnych formach. Poprzez deregulację,

29 Kapitalizm stoi w obliczu co najmniej trzech poważnych kryzysów. Kryzys zdrowotny wywołany pandemią szybko wywołał kryzys gospodarczy, którego konsekwencje dla stabilności finansowej są jeszcze nieznane, a wszystko to rozgrywa się na tle kryzysu klimatycznego, z którym nie można sobie poradzić w ramach „zwykłej działalności”. Zob. Mazzucato, 2020a.

30 Neoliberalizm stał się hegemoniczną ideologią zarówno krajowych, jak i międzynarodowych instytucji, takich jak m.in. Światowa Organizacja Zdrowia, Międzynarodowy Fundusz Walutowy, Bank Światowy, Parlament Europejski, Komisja Europejska. Konsekwencje jego zastosowania były olbrzymie, przyczyniając się w znacznym stopniu do powstania warunków sprzyjających ekspansji obecnej pandemii. Były prezydent Stanów Zjednoczonych Ronald Reagan i była premier Wielkiej Brytanii Margaret Thatcher rozpoczęli tę politykę pod koniec lat 70 . i na początku lat 80., a kontynuowali ją w Europie konserwatyści, liberałowie, a nawet socjaldemokraci. Zob. Navarro, 2020a. 
luki podatkowe, ulgi, reżimy handlowe oraz masowe pakiety ratunkowe struktur korporacyjnych „zbyt dużych, by upaść” - wielokrotnie wprowadzały wyrafinowane programy wsparcia. Deregulacja przepływu kapitału i siły roboczej doprowadziła do szerokiej, globalnej mobilności ludzi i produktów konsumenckich wraz z osłabieniem polityk chroniących pracowników i klientów. Również kompromitującą dla jakości życia ogółu była praktyka redukcji środków publicznych na usługi gwarantujące dobrostan ludności, takie jak opieka medyczna i publiczna służba zdrowia, a także usługi związane z filarem państwa opiekuńczego: żłobki, przedszkola i wsparcie dla osób niesamodzielnych (np. osób starszych). Usługi te mają zasadnicze znaczenie dla ograniczenia negatywnego wpływu pandemii na jakość życia ludzi ${ }^{31}$.

Wśród kryzysogennych czynników warto podkreślić zachowanie dużych firm farmaceutycznych, które systematycznie przedkładają swój cel maksymalizacji zysków nad wszelkie inne cele, takie jak zapobieganie i/lub leczenie chorób, które rozprzestrzeniając się - mogą przekształcić się w pandemię. To właśnie komercjalizacja medycyny i nadanie priorytetu interesom prywatnym nad publicznymi bardzo negatywnie wpłynęły na zdrowie i jakość życia milionów lu$\mathrm{dzi}^{32}$. Przykładowo międzynarodowa firma farmaceutyczna Big Pharma stanowi uosobienie sprzeczności między kapitałem a światowym zdrowiem. Przy wysokich cenach i zastrzeżonych patentach na leki, często opracowywanych przez publiczne instytucje badawcze, Big Pharma sprzedaje społeczeństwu produkt, który narodził się w wyniku badań finansowanych przez podatników. Jednocześnie zrezygnowała ona z opracowywania antybiotyków i leków przeciwwirusowych, których pilnie potrzebuje świat. Bardziej opłacalne jest wytwarzanie środków łagodzących męską impotencję niż wprowadzanie nowej generacji antybiotyków do walki z falą szczepów bakteryjnych, która zabija setki tysięcy pacjentów ${ }^{33}$.

W świetle raportu Światowej Organizacji Zdrowia, opublikowanego w lutym 2020 roku, warunki sprzyjające pozytywnej reakcji na pandemię to silne systemy społeczne i zdrowotne oraz kompleksowa strategia zwalczania epidemii. Warunki te obejmują: zdolność wykrywania zakażonych osób oraz opiekę

31 Ekonomiczne konsekwencje pandemii koronawirusa są rozległe i wpływają na sposób funkcjonowania światowej gospodarki. Można się wiele nauczyć, zaczynając od naszych poglądów na zdrowie i dobro publiczne po ewentualne zmiany w relacjach między zdrowiem, ekonomią i polityką. Zob. Lucchese, Pianta, 2020, s. 98-104.

32 Wychodząc z obecnego kryzysu, kraje mogą zrobić coś więcej niż tylko pobudzić wzrost gospodarczy; mogą pokierować tym wzrostem, aby zbudować lepszą gospodarkę. Zamiast udzielać bezwarunkowej pomocy korporacjom, mogą one uzależnić swoje dofinansowanie od polityki, która chroni interes publiczny i rozwiązuje problemy społeczne. Zob. Mazzucato, 2020a.

33 Nadszedł czas, aby ponownie przemyśleć partnerstwa publiczno-prywatne. Zbyt często te układy są mniej symbiotyczne, a bardziej pasożytnicze. Wysiłek mający na celu opracowanie szczepionki COVID-19 może stać się kolejną jednostronną relacją, w której korporacje czerpią zyski. Zob. Mazzucato, 2020b. 
nad osobami, które chorowały lub stanowią potencjalne niebezpieczeństwo zarażenia się ze względu na kontakty z osobami zakażonymi. Przyjęte rozwiązania obejmują zapewnienie, że system opieki zdrowotnej zachowa zdolność do obsługi rosnącej liczby pacjentów oraz gwarancję niezbędnych zasobów medycznych do opieki. Istnienie każdej z tych cech jest wskaźnikiem publicznego i zbiorowego zaangażowania oraz solidarności wobec wspólnego zagrożenia, przed którym stoją całe społeczeństwa ${ }^{34}$. W sytuacji prawdopodobieństwa nawracających infekcji, których charakter i dokładny czas pojawienia się są trudne do przewidzenia, należy zakładać, że system opieki zdrowotnej musi stać się bardziej elastyczny, zdolny do szybkiej relokacji zasobów.

Podstawowym przesłaniem stojącym przed większością krajów rozwiniętych jest niezdolność systemów opieki zdrowotnej do radzenia sobie z szybko rozprzestrzeniającą się infekcją. Jednak krytycznym wyzwaniem dla społeczeństwa i gospodarki okresu pandemii są wysokie społeczne koszty nierówności. Wydawać by się mogło, że w obliczu infekcji wirusa wszystko jest równe, ale są to wyjątki, które nie zmieniają ogólnej zasady: niższe warstwy społeczne są bardziej narażone na zakażenie i brak odpowiedniego leczenia. A im wyższy poziom nierówności majątkowych $\mathrm{w}$ kraju, tym bardziej selektywne jest $\mathrm{w}$ nim pokrycie programów socjalnych i usług medycznych. Przedstawiciele niższych warstw są częściej zatrudniani w sektorze usługowym, co sugeruje, że podczas pandemii albo kontynuowali pracę, narażając się na wysokie ryzyko infekcji, albo stracili jedyne źródło dochodu. Ponieważ ich praca jest często wykonywana poprzez samozatrudnienie, dostępność usług medycznych i świadczeń socjalnych zależy w dużej mierze od tego, jak chętnie państwo dostrzeże ich potrzeby.

Stosowanie polityk, takich jak deregulacja kapitału i pracy, obok polityki oszczędności, jest jednym z czynników, który przyczynił się do rozprzestrzeniania się takich zaburzeń po obu stronach Atlantyku ${ }^{35}$. Wzrost stymulowany poprzez globalizację, migrację i technologię doprowadził do pogłębienia nierówności dochodów i majątku, co z kolei prowadzi do niepokojów społecznych. Tradycyjnej demokracji liberalnej zagraża radykalny populizm - albo ze strony skrajnej lewicy, albo skrajnej prawicy. Wbrew powszechnemu przekonaniu, że kryzys „unieważnia” dotychczasowe porozumienia, stwarzając przestrzeń dla radykalnych przemian społecznych, dzisiejsze środki reagowania na niepewność

34 Zgodnie z tymi kryteriami niedawny artykuł w czasopiśmie „Lancet” pokazuje, że skuteczna strategia powstrzymywania, zastosowana przez Japonię, Hongkong i Singapur (do których należy dodać Koreę Południową), a także Chiny, była możliwa dzięki tym warunkom. Oznaczało to, że publiczne służby medyczne i socjalne były w stanie kontrolować zarówno rozprzestrzenianie się epidemii, jak i opiekę nad chorymi. Są też kraje, którym brakuje tych cech w wyniku neoliberalnej polityki oszczędnościowej wprowadzonej przez ich rządy. Zob. Navarro, 2020a.

35 Pod wpływem idei neoliberalnych w ciągu ostatnich lat służba zdrowia była systematycznie komercjalizowana i optymalizowana, a po kryzysie lat 2008-2009 redukcja wydatków socjalnych w maksymalnym stopniu wpłynęła na opiekę zdrowotną. Zob. Navarro, 2020b, s. 271-275. 
sytuacji kryzysowej z reguły opierają się na istniejących decyzjach i programach ${ }^{36}$. Obywatele otrzymują różnego rodzaju opiekę w zależności od ich pozycji społecznej, a co za tym idzie doświadczają polaryzacji, która podważa solidarność potrzebną do rozwiązania ogromnych problemów wywołanych przez pandemię. Szeroka kontrola, jaką siły konserwatywne - z neoliberalną wrażliwością - sprawowały i nadal sprawują nad aparatem państwowym oraz instytucjami politycznymi i medialnymi, doprowadziła do sytuacji, która ujawnia ogromne deficyty, często uciszane lub ukrywane przez wspomniany establishment $t^{37}$.

Trudno oczekiwać skutecznego antidotum na powyższe problemy, aby dostosować się do aplikowanego projektu elastycznego wzorca rynku. Dzisiaj szczególnie widać, że to nie rynek, ale polityka odpowiada za pomyślność państwa. Polityka ośmiesza się, gdy moralizuje, zamiast pełnić funkcję demokratycznego ustawodawcy, który ma moc ustanawiania obowiązującego prawa. Kompromitacji uległa polityka, która bezwzględnie preferowała interesy inwestorów, godziła się na wzrost nierówności społecznych, niepewność jutra czy niski poziom płac. Zdyskredytował się sposób uprawiania polityki, który w prywatyzacyjnym szaleństwie, odbierając państwu jego fundamentalne prawa, przekształcał je w „atrapę”, oddając ostatki swoich zobowiązań w dzierżawę mnożącym zyski inwestorom finansowym, a sferę kultury i oświaty uzależniał od interesów i nastrojów sponsorów, zależnych od koniunktury. Dopóki społeczeństwo w swojej masie jest odsuwane od istotnych kwestii dotyczących warunków stabilności i rozwoju oraz rzeczywistego wpływu na procesy polityczne, dopóty może być traktowane jako zatomizowana grupa indywiduów.

Kryzys obecnych czasów jest definiowany przez niezdolność idei neoliberalizmu do generowania rozwiązań i projektów służących większości ludzi, do zapewnienia miejsc pracy, zakończenia emisji paliw kopalnych i przełożenia postępów biologicznych na zdrowie publiczne. Są to zbieżne kryzysy, nierozerwalnie związane z sobą i należy je postrzegać jako całość, a nie jako odrębne kwestie. Dezinformacja, szeroko rozpowszechniana przy pomocy dzisiejszych technologii komunikacyjnych, stworzyła „infodemię” w pandemii, zmniejszając zaufanie do nauki oraz znacznie utrudniając przedstawicielom i ekspertom zdrowia publicznego podejmowanie działań i środków naprawczych. Trudno w takiej sytuacji

36 Mamy globalne zmiany klimatyczne z pandemiami i jednocześnie powstają wielkie technologie oraz państwa nadzoru i inwigilacji. Tak więc istnieje wiele skomplikowanych kwestii, które stanowią wyzwanie dla tradycyjnych gospodarek rynkowych i liberalnych demokracji. Zob. Kunica, 2020.

37 Rozszerzenie logiki politycznej, wplecionej w agendę polityki gospodarczej, sprawiło, że neoliberalizm płynnie wkroczył w istniejące ramy, które wyraźnie sięgają sfer politycznych i ekonomicznych oraz kulturowych. Zob. Golinowski, 2019, s. 31. 
zwalczać fałszywe narracje i skutecznie przekazywać polecenia decydentom i opinii publicznej. Strach i panika w mniejszym stopniu wynikają z ryzyka infekcji, a bardziej z rosnącej perspektywy upadku status quo. Obecnie nastał czas, aby przyszłość stała się podstawą krytycznego stosunku do wzorca neoliberalnego, który jest korzystny tylko dla jego twórców. Przestrzeganie neoliberalnego paradygmatu małych państw i maksymalne przeniesienie odpowiedzialności za kształtowanie dobrobytu na barki obywateli i ich rodzin utrudnia przyszły rozwój gospodarczy i działa jako czynnik niestabilności politycznej.

Pandemia COVID-19 rzuciła światło na zagrożenia społeczne, gospodarcze i środowiskowe, które narastały przez ostatnie dekady. W obliczu niepewności globalnej sytuacji nadszedł czas, aby kwestionować stare założenia i opracować nowe rozwiązania instytucjonalne. Dysfunkcje instytucji w następstwie koronawirusa stały się oczywiste dla ogółu społeczeństw. To popycha ludzi i państwa w kierunku większej niezależności przy podejmowaniu decyzji o odpowiedzialności za własne przetrwanie, stąd „zmiennośćc i impulsywność zachowań społecznych. W rezultacie ludzie i poszczególne państwa w mniejszym stopniu kierują się algorytmami instytucjonalnymi i coraz bardziej polegają na własnych partykularnych interesach, często chwilowych i błędnych. Żadne wydarzenie od zakończenia II wojny światowej nie miało takiego wpływu jak obecna pandemia. Wywołała ona kryzys zdrowia publicznego i gospodarczy na skalę niespotykaną od pokoleń i zaostrzyła problemy systemowe, takie jak nierówności i podstawy legitymacji wszelkiej władzy. Pochód koronawirusa tylko stymulował procesy, które powstały przed jego pojawieniem. Jednak ze względu na skalę oraz wpływ na stosunki społeczne pandemia wyznaczyła symboliczną linię pod istnieniem pewnego porządku i - jak można sądzić - stała się początkiem kolejnego.

\section{Literatura}

Barber, B.R. (2008). Skonsumowani. Jak rynek psuje dzieci, infantylizuje dorostych i polyka obywateli. Warszawa: Wydawnictwo Literackie Muza.

Bauman, Z. (1995). Wieloznaczność nowoczesna - nowoczesność wieloznaczna. Warszawa: Wydawnictwo Naukowe PWN.

Beck, U., Beck-Gemsheim, E. (2002). Individualization: Institutionalized Individualism and its Social and Political Consequences. London-Thousand Oaks-New Delhi: Sage Publications.

Bird, E. (2009). „Tabloidization: What Is It, and Does It Really Matter?”. W: B. Zelizer (ed.). The Changing Faces of Journalism: Tabloidization, Technology and Truthiness. New York: Routledge.

Bo Karlsson, M. (2016). „Goodbye Politics, Hello Lifestyle. Changing News Topics in Tabloid, Quality and Local Newspaper Websites in the U.K. and Sweden from 2002 to 2012". Observatorio, 10(4), s. 162. 
Bruff, I. (2014). „The Rise of Authoritarian Neoliberalism”. A Journal of Economics, Culture \& Society, 26.

Bruno, V.A., (2018). „The Production of Fear: European Democracies in the Age of Populisms and Technocracies". Social Europe, June 13.

Brysk, A. (2020). „Global Dynamics of Authoritarian Populism”. Global-e, 18 February, Vol. 13, Issue 9, https://www.21global.ucsb.edu/global-e/february-2020/global-dynamics-authoritarian-populism (dostęp: 18.10.2020).

Cahill, D. (2012). „The Embedded Neoliberal Economy”. W: D. Cahill, L. Edwards, F. Stilwell (eds.). Neoliberalism: Beyond the Free Market. Cheltenham: Edward Elgar.

Campbell, C. (2006). „Kupuję, więc wiem, że jestem. Metafizyczne podstawy nowoczesnego konsumeryzmu”. Kultura Popularna, 4(18).

Centeno, M.A., Cohen, J.N. (2012). „The Arc of Neoliberalism”. Annual Review of Socio$\log y, 38(1)$.

Collier, S.J. (2012). „Neoliberalism as Big Leviathan, or...? A Response to Wacquant and Hilgers". Social Anthropology, 20(2).

Foucault, M. (1993). Nadzorować i karać. Narodziny więzienia. Warszawa: Aletheia.

Foucault, M. (1998). Trzeba bronić społeczeństwa. Wykłady z Collège de France 1976. Warszawa: Wydawnictwo KR.

Foucault, M. (2000a). Historia seksualności. Warszawa: Wydawnictwo Czytelnik.

Foucault, M. (2000b). Historia seksualności. Wola wiedzy, t. 1. Warszawa: Wydawnictwo Czytelnik.

Foucault, M. (2008). Birth of Biopolitics: Lectures at the Collège de France 1978-1979. New York: Palgrave Macmillan.

Fuchs, Ch. (2018). „Propaganda 2.0: Herman and Chomsky's Propaganda Model in the Age of the Internet, Big Data and Social Media”. W: J.P. Carañana, D. Broudy, J. Klaehn (eds.). The Propaganda Model Today: Filtering Perception and Awareness. London: University of Westminster Press.

Furedi, F. (2003). Therapy Culture: Cultivating Vulnerability in an Uncertain Age. London: Routledge.

Furedi, F. (2020). Why Borders Matter: Why Humanity Must Relearn the Art of Drawing Boundaries. London: Taylor \& Francis.

Ghosh, A.R., Ostry, J.D., Qureshi, M.S. (2016). „When Do Capital Inflow Surges End in Tears?”. American Economic Review, 5(106).

Golinowski, J. (2018). „Pomiędzy awangardą neoliberalnej zmiany a demontażem procesów instytucjonalizacji”. W: W. Bulira (red.). Granice teorii polityki. Świat zachodni $w$ stanie zagrożenia. Lublin: Wydawnictwo UMCS.

Golinowski, J. (2019). „Państwo wobec darwinistycznych tendencji współczesnej gospodarki”. Transformacje, 1-2(100-101), http://www.e-transformations. com/archiwum/transformacje_1-2_2019.pdf (dostęp: 11.09.2020).

Gray, J. (2009). Czarna Msza. Apokaliptyczna religia i śmierć utopii. Kraków: SIW Znak.

Green, S. (1999). „A Plague on the Panopticon: Surveillance and Power in the Global Information Economy". Information, Communication \& Society, 2.

Habermas, J. (2003). Przyszłość natury ludzkiej. Czy zmierzamy do eugeniki liberalnej? Warszawa: Wydawnictwo Naukowe Scholar.

Howard, P.N., Carr, J.N., Milstein, T.J. (2005). „Digital Technology and the Market for Political Surveillance". Surveillance \& Society, 3(1). 
Johnston, J., Szabo, M. (2011). „Reflexivity and the Whole Food Market Consumer: The Lived Experience of Shopping for Change". Agriculture and Human Values, 28.

Kreft, J. (2019). Władza algorytmów. U źródeł potęgi Google i Facebooka. Kraków: Wydawnictwo Uniwersytetu Jagiellońskiego.

Kunica, M. (2020). Pandemie moga się powtarzać. Wielu straci pracę. Wielu wpadnie w ubóstwo. Tylko u nas Nouriel Roubini o najważniejszych wyzwaniach dla świata, https://businessinsider.com.pl/finanse/makroekonomia/nouriel-rubini-w-business-insider-polska-onajważniejszych-wyzwaniach-dla-świata/wsv8xyk (dostęp: 30.10.2020).

Kutiyski, Y., Krouwel, A., van Prooijen, J.W. (2019). „Political Extremism and Distrust: Does Radical Political Orientation Predict Political Distrust and Negative Attitudes Towards European Integration?". The Social Science Journal, https://www.tandfonline.com/doi/full/10.1016/j.soscij.2019.03.004 (dostęp: 20.10.2020).

Leggett, W. (2014). „The Politics of Behaviour Change: Nudge, Neoliberalism and the State". Policy \& Politics, 1(42).

Lemert, Ch.C., Gillan, G. (1999). Michel Foucault. Teoria społeczna i transgresja. Warszawa-Wrocław: Wydawnictwo Naukowe PWN.

Lemke, T. (2001). „The Birth of Bio-politics: Michel Foucault's Lecture at the Collège de France on Neo-liberal Governmantality”. Economy and Society, 30(2).

Lemke, T. (2010). Biopolityka. Warszawa: Wydawnictwo „Sic!”.

Lemke, T. (2011). „Analityka biopolityki. Rozważania o przeszłości i teraźniejszości spornego pojęcia”. Praktyka Teoretyczna, 2-3, s. 14.

Lilja, M., Vinthagen, S. (2014). „Sovereign Power, Disciplinary Power and Biopower: Resisting What Power with What Resistance?". Journal of Political Power, 7.

Lucchese, M., Pianta, M. (2020). „The Coming Coronavirus Crisis: What Can We Learn?”. Intereconomics Review of European Economic Policy, 55.

Mazzucato, M. (2020a). „Capitalism After the Pandemic, Getting the Recovery Right”. Foreign Affairs, November/December.

Mazzucato, M. (2020b). „Capitalism's Triple Crisis”. Social Europe, 9th April.

McGoey, L. (2007). „On the Will to Ignorance in Bureaucracy”. Economy and Society, $36(2)$.

Navarro, V. (2020a). „The Consequences of Neoliberalism in the Current Pandemic”. International Journal of Health Services, May 7, https://www.ncbi. nlm.nih.gov/pmc/ articles/ PMC7218352/ (dostęp: 25.10.2020).

Navarro, V. (2020b). „The Consequences of Neoliberalism in the Current Pandemic”. International Journal of Health Services, 50(3).

Peters, M.A. (2007). „Foucault, Biopolitics and the Birth of Neoliberalism”. Critical Studies in Education, 48.

Peters, M.A. (2018). „The End of Neoliberal Globalisation and the Rise of Authoritarian Populism". Educational Philosophy and Theory, 50.

Piketty, T. (2015). Kapitał w XXI wieku. Warszawa: Wydawnictwo Krytyki Politycznej.

Rabinow, P., Rose, N. (2006). „Biopower Today”. BioSocieties, 1(2).

Sloterdijk, P. (2003). Pogarda mas. Szkic o walkach kulturowych we współczesnym społeczeństwie. Warszawa: Czytelnik.

Van Apeldoorn, B., Overbeek, H. (2012). „Introduction: The Life Course of the Neoliberal Project and the Global Crisis”. W: H. Overbeek, B. van Apeldoorn (eds.). Neoliberalism in Crisis. London: Palgrave Macmillan. 


\section{Streszczenie}

Technologie usprawniające działanie człowieka rodzą poważne pytania etyczne dotyczące praktyk zdrowotnych, które nie służą już tylko leczeniu chorób, ale proponują również „optymalizację” fizycznych, poznawczych i psychologicznych zdolności ludzi. W tym artykule dokonujemy koncepcyjnego wyjaśnienia pojęć biowładzy i biopolityki oraz argumentujemy za ich użytecznością we współczesnej analizie. Trzy dekady neoliberalnej polityki poważnie ograniczyły państwo opiekuńcze: prywatyzacje i cięcia w budżetach publicznych zmusiły agencje publiczne do ograniczenia swojej działalności, co niejednokrotnie prowadziło do utraty przez nie uniwersalności, skuteczności oraz do obniżenia jakości usług. Pandemia dramatycznie pokazała cenę takiego neoliberalnego zwrotu. Globalizacja rynku stwarza zagrożenia dla zdrowia i nie jest w stanie reagować na sytuacje kryzysowe. Prywatna opieka zdrowotna okazuje się w dużej mierze nieistotna $\mathrm{w}$ walce $\mathrm{z}$ pandemią. Państwo opiekuńcze nie powinno być traktowane jako „koszt” dla prywatnego systemu gospodarczego. Byłoby błędem sądzić, że po ustąpieniu pandemii gospodarka mogłaby wrócić do „normalności”. Musimy ponownie przemyśleć produkcję i konsumpcję w świetle potrzeb zdrowotnych i środowiskowych.

Słowa kluczowe: panoptykon biopolityki, neoliberalna droga rozwoju, kryzys, technologie cyfrowe, społeczna terapia 